The Review of Finance and Banking

Volume 13, Issue 2, Year 2021

http://dx.doi.org/10.24818/rfb.21.13.02.04, Pages 135-146

S print ISSN 2067-2713 online ISSN 2067-3825

\title{
GOVERNMENTAL ANNOUNCEMENTS AND INDIAN STOCK MARKET: EVIDENCE FROM INDIAN MANUFACTURING SECTOR
}

\author{
MAHESH DAHAL AND JOY DAS
}

\begin{abstract}
The Indian Manufacturing sector lags behind in contributing to economic development, as compared to its peer nations and therefore, to boost the sector's contribution to the economy and to transform the economy into a cashless economy, the government of India had announced three major steps, Make in India, Demonetization and GST. In the present study using event study methodology, the immediate impact of the announcements on the stock of the companies from the Indian Manufacturing sector is examined and found that the announcement of the Make in India positively influenced the security returns. In contrast, negative impact on the security prices is witnessed on the announcement of Demonetization, whereas the GST implementation has no impact.
\end{abstract}

\section{INTRODUCTION}

Indian economy, the fastest growing economy in the world, which is also growing as a hotspot for investment among the world's emerging nations (Thippeswamy, 2018), is lagging in the manufacturing sector compared to other sectors of the economy. It becomes more evident when the contribution of the manufacturing sector to the GDP of India is observed (India Brand Equity Foundation, 2015), (Bhat, 2014), (Mehta \& A, 2017). In a growing economy, the development of the manufacturing sector is of great significance as the industry's contribution to the overall development of a nation is crucial (Cantore et al., 2017), (Haraguchi, Cheng, \& Smeets, 2017), (Fernandez \& Palazuelos, 2018) as observed in developing countries like Thailand, China and Indonesia, where the industry contributes 25 percent; 27 percent; and 20 percent to GDP respectively (Szirmai \& Verspagen, 2015). In contrast, the Indian manufacturing sector contributes only 14 percent to GDP, which can be a setback for economic growth (The World Bank, 2019).

Taking into account the importance of the Manufacturing sector, the government of India, between the years 2014 to 2019, has taken three major steps. First, the "Make in India" in September of 2014, a landmark step taken toward enhancing the manufacturing capacity and encouraging the productivity of the Indian firms. The campaign mainly stressed stimulating domestic investment, improving the ease of doing business and attracting foreign investment in the manufacturing sector. The government identified 25 (twenty-five) sectors, including Textiles, Food Processing, Defense, Railways, Construction, and Tourism, for leading the campaign with almost 100\% FDI (Sawhney, 2016; Shukla, Purohit, \& Gaur, 2017). Second, to curb corruption and black money Government of India, on November 8, 2016, announced 'Demonetization.' Among other sectors, the manufacturing sector of India was also affected by the Demonetization,

Received by the editors September 7, 2021. Accepted by the editors December 23, 2021.

Keywords: Indian Manufacturing Sector, Make in India, Demonetization, GST Implementation, Event Study Methodology.

JEL Classification: G11, G14, G18.

Mahesh Dahal, PhD Student*(Corresponding Author), Research Scholar, Department of Commerce, Tripura University, Suryamaninagar, Tripura- 799022. E-mail: maheshdahal118@gmail.com.

Joy Das, PhD, Assistant Professor, Department of Commerce, Tripura University, Suryamaninagar, Tripura799022. E-mail: joy.kxj@gmail.com.

This paper is in final form and no version of it will be submitted for publication elsewhere. 
as evident from the previous researches done by Katke, et al., (2015); Chadha \& Sharma, (2017); Sarkar \& Dutta (2017) and Neelam (2017). Third and the most important announcement by the government of India in the form of reform in the indirect tax regime, launched on July 1, 2017 'Goods and Services Tax (GST).' The GST has transformed the financial architecture by merging the various indirect taxes like VAT, and sales tax. Under the new tax regime, both the center and state shall share power in levying and collecting tax, thereby restoring a fiscal balance. It will also bring efficiency to the Indian economy by lowering and rationalizing the tax burden (The Economic Times, 2020).

All the events not only impacted the Indian economy but the Indian stock market has also been impacted by these events, as evident from previous studies. However, the reactions of the stock market around the said events are not consistent. In the case of the make in India announcement, none of the studies has addressed the market reaction. At the same time, the market reactions around demonetization announcements are contradictory. Chauhan \& Kaushik (2017), Solanki \& Tank (2018), Jain \& Gupta (2018), and Agrawal \& R (2019) found no impact of Demonetization on the Indian stock market, while Anoop et al. (2018), Taqi et al. (2018), and Kumar \& Bhatia (2018) have found a significant impact of Demonetization. In the case of GST announcement, very less studies have been conducted to see the stock market reactions and in that also the differences in opinion exists among researchers regarding its impact on the Indian stock market. Saran (2018), Girish (2019) have found a significant impact of the GST announcement, while Mehta (2020) found no impact of the GST announcement on the stock returns.

The limited number of studies and their concentration, particularly on the overall market, have been the cause for carrying the study. Sector and industry play a crucial role in overall market behavior, but the previous studies have ignored the importance of the sectors entirely. Moreover, among the sectors, Manufacturing is the one that has been center of the announcements like 'Make in India.' Therefore, the present study has been undertaken to answer the queries regarding the behavior of the manufacturing sector stocks around the major governmental announcement. The study shall consider the events, namely, Make in India, Demonetization and the GST implementation and will study the market reaction around the said events.

\section{Review of Literature}

Examination of the impact and reaction of the stock market to the various firms' specific, micro and macro events have been a significant concern among the scholars and experts of the finance literature. Some of the relevant studies have been reviewed in the present study.

Thomas \& Shah (2002) studied the reaction of the Indian stock market to the announcement of the union budget from 1979 to 2001 and found that the Indian stock market processes the information contained in the budget smoothly and concluded that the Indian stock market is efficient. In another study by Mohanty (2008) the market reaction on the positive and negative news about the celebrity, who endorsed a particular product is studied and found that any positive news about that celebrity has added value to the firm and simultaneously eroded the value of the competing firms. However, the negative news about celebrity has no impact on the firm's market value. Another critical study by Khanna \& Gogia (2014), considering the budget announcement of India, the US and the UK, concluded that in the case of India and the UK, the budget's impact is short and medium-term. As days passed, the information was adjusted in the securities prices. However, in the case of the US, the budget affects the market in the long run and not in the short and medium-term. A similar study by Panwar \& Nidugala (2017) on the Indian market around inflation and interest rate announcements was conducted and found that inflation impacted the market positively. In contrast, the impact of repo rate and inflation was not uniform across the sectors.

The major announcements by the government of India also have a crucial area of researches as the announcements have a potential impact on the stock market. A study by Chauhan \& Kaushik (2017) analyzed the impact of demonetization announcements on S \& P 100 companies 
using an event study and found that Demonetization has no impact on the Indian stock market. Similar results were found by Solanki \& Tank (2018), Jain \& Gupta (2018), and Agrawal \& R (2019). However, opposing viewpoints were presented showing the impact of Demonetization on the Indian Stock Market by Anoop et al. (2018), where the study found that Demonetization has a significant negative impact on the stock market. Demonetization has significantly impacted almost all the sectoral indices of NSE negatively. Supporting this result, Taqi et al. (2018) also revealed that Demonetization has affected the Indian stock market. A similar study by Kumar \& Bhatia (2018) found that the automobile sector and realty sector are much affected by the announcement, whereas BSE bank has been positively impacted, and the FMCG sector is least affected by the announcement of Demonetization. Another important event that changed the tax regime of India, i.e., Goods and Services tax, has also been studied by Girish (2019) using event study methodology and concluded that the implementation of the GST has a positive impact on NSE nifty 50. A similar study was conducted by Saran (2018) using OLS, GARCH, and TGARCH found that Pharma and PSU Bank have been impacted positively while Auto, IT, and Realty have been impacted negatively. Similarly, Sharma \& Sain (2017) also found the positive impact of GST on different sectors and industries. However, Mehta (2020), in the study on the selected companies of the BSE realty index, found no impact of the implementation of the GST on the realty sector.

\begin{tabular}{|c|c|c|c|c|}
\hline Authors & Stocks & Methodology & Events & Conclusion \\
\hline $\begin{array}{l}\text { Chauhan \& Kaushik (2017), } \\
\text { Jain \& Gupta (2018) }\end{array}$ & Top BSE companies & $\begin{array}{l}\text { Event Study } \\
\text { Methodology }\end{array}$ & Demonetization, & No impact \\
\hline Solanki \& Tank (2018) & BSE Indices & $\begin{array}{l}\text { Event Study } \\
\text { Methodology }\end{array}$ & Demonetization & No impact \\
\hline Agrawal \& R (2019) & NSE Indices & $\begin{array}{l}\text { Event Study } \\
\text { Methodology } \\
\text { and Granger } \\
\text { Causality }\end{array}$ & Demonetization & No impact \\
\hline Anoop et al., (2018) & Sectoral Indices of NSE & GARCH & Demonetization & Negative impact \\
\hline Taqi et al., (2018) & BSE Companies & $\begin{array}{l}\text { Event Study } \\
\text { Methodology }\end{array}$ & Demonetization & Negative impact \\
\hline Kumar \& Bhatia (2018) & Sectoral indices of BSE & $\begin{array}{l}\text { Event Study } \\
\text { Methodology }\end{array}$ & Demonetization & $\begin{array}{l}\text { Positive impact on BSE } \\
\text { Bank and negative on au- } \\
\text { tomobile and realty. }\end{array}$ \\
\hline Girish (2019) & Nifty 50 & $\begin{array}{l}\text { Event Study } \\
\text { Methodology }\end{array}$ & GST & Positive impact \\
\hline Saran (2018) & Sectoral indices & $\begin{array}{l}\text { GARCH } \\
\text { TGARCH }\end{array}$ & GST & $\begin{array}{l}\text { Positive impact on Pharma } \\
\text { and PSU Bank, negative on } \\
\text { Auto, IT, and Realty }\end{array}$ \\
\hline Sharma \& Sain (2017) & Sectoral indices & $\begin{array}{l}\text { Event Study } \\
\text { Methodology }\end{array}$ & GST & Positive impact \\
\hline Mehta (2020) & BSE reality index & $\begin{array}{l}\text { Event study } \\
\text { methodology }\end{array}$ & GST & No impact \\
\hline
\end{tabular}

One of the major events, 'Make in India' launched with an aim to boost the Indian manufacturing sector that has been the part of this study has been studied extensively by Sagar (2016), Gulhane \& Turukmane (2017), Srivastava (2019), Barwer \& Sharma (2019), Shettar (2017), Sheoran (2017), Gaur \& Padiya (2017), Kumar \& Dubey (2016), Shukla et al. (2017), Gauba et al. (2016), Mishra \& Taruna (2016), and Sahoo (2018). But none of the studies focused on the impact of Make in India on the stock market.

An important point to be noted here is that all the events under study have similar patterns with respect to the sample selection and methodology. None of the studies has considered the importance of sectors and the firms constituting the sectors. Among sectors, the manufacturing sector is the one that has a crucial role in the development of both the economy and the capital 
market. Therefore, the present study has been undertaken to bridge the literature gap and examine the behavior of manufacturing sector stocks on the announcement of major government policies and programs.

This paper is the first of its kind to study three major governmental announcements and their impact on the stock market. The study shall add new literature to the existing literature work. It will also be beneficial to the investors in managing portfolios in the events of major governmental policies and changes. It will also reflect the perception of the investors regarding the particular governmental announcement.

Objectives of the study: The main objective of the paper is to examine the behavior of the stock of the companies from the Indian Manufacturing sector around the major government announcements. For this purpose, the paper is based on three specific objectives:

1. To examine the reaction of the security price around the announcement of the Make in India initiation;

2. To observe the reaction of the security price around the announcement of the Demonetization; and

3. To examine the security price reaction around the announcement of the GST implementation.

\section{Data and Methodology}

3.1. Sample and period of the study. The sample companies for the study are primarily based on market capitalization and listing on the stock exchanges of India. The present study has taken the top twenty (20) manufacturing companies, forming more than 75 percent of the total market, based on market capitalization as per moneycontrol.com.

\begin{tabular}{|c|c|}
\hline \multicolumn{2}{|c|}{$\begin{array}{c}\text { Table No.2 Samples under study } \\
\text { (Indian Manufacturing Companies) }\end{array}$} \\
\hline Maruti Suzuki & Cipla \\
\hline Nestle & Hero Motocorp \\
\hline Sun Pharma & Eicher Motors \\
\hline UltraTechCement & AurobindoPharm \\
\hline Britannia & Lupin \\
\hline Bajaj Auto & Torrent Pharma \\
\hline Shree Cements & Cadila Health \\
\hline Dr. Reddys Labs & Ambuja Cements \\
\hline $\mathrm{M} \& \mathrm{M}$ & Abbott India \\
\hline Divis Labs & Bosch \\
\hline & \\
\hline
\end{tabular}

The study made use of the daily closing prices of these companies, which have been collected from the BSE India official website. And BSE Sensex is taken as the proxy of the Indian stock market for the study.

For the purpose of the study, the data is divided into two parts, the pre-announcement period and the post-announcement period, to analyze the impact of the respective events.

\begin{tabular}{|c|c|}
\hline Table No.3 Events and their announcement date \\
\hline Events used in the study & Announcement Date \\
\hline Make in India & September 25, 2014 \\
\hline Demonetization & November 8,2016 \\
\hline GST implementation & July 1, 2017 \\
\hline \multicolumn{2}{|c|}{ Source: Compiled by Author } \\
\hline
\end{tabular}

GST implementation was launched at midnight on July 1, 2017; therefore, the event date is July 2, but July 2 was Sunday (holiday). Therefore, the final event date is considered to be July $3,2017$. 
3.2. Event Study Methodology. It is used to detect the behavior of security prices around the different events (Fama et al. 1969), (Brown, 1980). The event study detects the difference between expected and actual security prices and tests the significance of the difference. The following steps are involved in the event study based on Peterson (1989), Mackinlay (1997), Anwar, et al., (2017) and Dahal \& Das (2020).

Event window: An event window is a period within which the impact of the event is analyzed. In the present study, 21 days event window $(-10 \ldots . \ldots \ldots+10)$ is considered.

Here, " -10 day to -1 day" are the days prior to the announcement of the event.

" 0 day" is the day on which the announcement was made.

" +1 day to +10 days" are the days after the announcement of the events.

Estimation period: The parameters alpha $(\alpha)$ and beta $(\beta)$ are estimated during this period. An estimation period of 120 days prior to the event window is considered in the study.

Here, "-130 day to -11 day" is the estimation period in the present study.

Return calculation: A log return of security ' $\mathrm{j}$ ' on time ' $\mathrm{t}$ ' is calculated.

$$
R_{j t}=\ln \left(p_{j t} / p_{j t-1}\right)
$$

Here,

$R_{j t}=$ Return of security 'j' at time ' $\mathrm{t}$ '.

$p_{j t}=$ Price of security ' $\mathrm{j}$ ' at time ' $\mathrm{t}$ '.

$p_{j t-1}=$ Price of security ' $\mathrm{j}$ ' at time ' $\mathrm{t}-1$ '.

Model Estimation: OLS Market Model, also known as the Risk-Adjusted Model of Sharpe (1964), is used in the study for calculating the Expected Return E (R) of the securities.

$$
E(R)=\alpha+\beta * R_{m t}
$$

Here, $E(R)$ is the expected return, $\alpha$ and $\beta$ are parameters estimated from the estimation period and Rm,t is the return of BSE Sensex.

Calculation of Abnormal Return: It is the difference between the actual return and expected return. The actual return is calculated from eq. 1, and the expected return from eq. 2 .

$$
\text { AbnormalReturn }=R_{j t}-E(R)
$$

Calculation of Average Abnormal Returns (AARs) and Cumulative AARs (CAARs): It is calculated as:

$$
\mathbf{A A R s}=\sum_{t=1}^{N} \mathrm{AR}_{\mathrm{jt}} / N
$$

Here,

$A R_{j t}$ is the abnormal return of security ' $\mathrm{j}$ ' on time ' $\mathrm{t}$ '.

$N$ is the number of firms under study.

$$
\operatorname{CAARs}(t, t+1)=\sum_{t=t}^{t+1} \operatorname{AARs}
$$

Here, the average abnormal returns are aggregated across all the days (from -10 to +10 in the present study) to measure the cumulative effect on sample securities under study.

Significance testing of AARs and CAARs: The significant test at $5 \%$ significance level is tested using T- Statistics. It is helpful in assessing the impact of events with respect to AARs and CAARs.

$$
T-S t a t s \_A A R s=A A R s /[S D(A A R s) / \sqrt{N}]
$$




$$
T-S t a t s \_C A A R s=C A A R s /[S D(C A A R s) / \sqrt{N}]
$$

\section{Data Analysis and Interpretation}

Impact of Make in India: In table no. 4. AARs and CAARs, along with t-statistics and other relevant information like standard deviation, skewness and kurtosis, are presented to analyze the impact of Make in India initiation on Indian manufacturing sector companies.

\begin{tabular}{|c|c|c|c|c|c|c|c|c|c|c|}
\hline \multicolumn{11}{|c|}{ Table No.4 Impact of Make in India } \\
\hline Event & $\operatorname{AARS}(\%)$ & T-Stats & $\mathrm{CAARs}(\%)$ & T-Stats & Median & Min & Max & StdDev & Skewness & Kurtosis \\
\hline Days & & & & & $\operatorname{AR}(\%)$ & $\operatorname{AR}(\%)$ & $\operatorname{AR}(\%)$ & $\operatorname{AR}(\%)$ & & \\
\hline-10 & 0.92 & $7.41^{*}$ & 0.92 & 1.61 & 0.09 & -4.66 & 15.44 & 3.98 & 2.65 & 9.62 \\
\hline-9 & 0.61 & $4.92^{*}$ & 1.54 & $2.68^{*}$ & 0.33 & -2.70 & 5.82 & 2.16 & 0.52 & 0.18 \\
\hline-8 & 0.31 & $2.48^{*}$ & 1.85 & $3.22 *$ & 0.02 & -3.26 & 5.37 & 2.03 & 0.86 & 0.94 \\
\hline-7 & -1.34 & $-10.72 *$ & 0.51 & 0.89 & -0.98 & -5.90 & 1.50 & 2.11 & -0.58 & -0.61 \\
\hline-6 & -0.22 & -1.82 & 0.28 & 0.49 & -0.07 & -4.08 & 2.46 & 1.47 & -0.66 & 1.21 \\
\hline-5 & 0.68 & $5.47^{*}$ & 0.97 & 1.68 & 0.83 & -3.09 & 3.64 & 1.70 & -0.32 & 0.13 \\
\hline-4 & -0.59 & $-4.72 *$ & 0.38 & 0.66 & -0.81 & -3.24 & 1.44 & 1.38 & -0.24 & -0.82 \\
\hline-3 & -0.48 & $-3.87 *$ & -0.10 & -0.18 & -0.61 & -2.71 & 3.62 & 1.389 & 1.22 & 2.94 \\
\hline-2 & -0.56 & $-4.49^{*}$ & -0.66 & -1.15 & -0.28 & -5.22 & 2.22 & 1.94 & -1.03 & 0.87 \\
\hline-1 & -0.09 & -0.71 & -0.75 & -1.31 & -0.26 & -2.21 & 2.93 & 1.30 & 0.66 & 0.43 \\
\hline 0 & 0.05 & 0.41 & -0.70 & -1.22 & -0.33 & -3.81 & 7.75 & 2.19 & 2.21 & 8.25 \\
\hline 1 & 0.39 & $3.14^{*}$ & -0.31 & -0.54 & 0.40 & -2.65 & 3.82 & 1.72 & 0.25 & -0.47 \\
\hline 2 & 0.68 & $5.43^{*}$ & 0.36 & 0.63 & 0.37 & -1.41 & 6.79 & 1.97 & 1.84 & 3.98 \\
\hline 3 & 0.31 & $2.51^{*}$ & 0.68 & 1.18 & 0.27 & -3.79 & 5.50 & 1.89 & 0.58 & 2.47 \\
\hline 4 & -0.24 & -1.92 & 0.44 & 0.76 & -0.55 & -3.09 & 3.21 & 1.49 & 0.55 & 0.40 \\
\hline 5 & -0.91 & $-7.27^{*}$ & -0.46 & -0.81 & -1.07 & -3.67 & 2.73 & 1.76 & 0.33 & -0.35 \\
\hline 6 & -1.40 & $-11.2^{*}$ & -1.87 & $-3.24^{*}$ & -0.46 & -4.70 & 0.94 & 1.79 & -0.69 & -0.66 \\
\hline 7 & -0.10 & -0.82 & -1.97 & $-3.42^{*}$ & 0.06 & -2.11 & 1.95 & 1.25 & 0.01 & -1.02 \\
\hline 8 & -0.75 & $-6.01 *$ & -2.72 & $-4.73^{*}$ & -0.60 & -2.77 & 2.07 & 1.25 & 0.17 & -0.18 \\
\hline 9 & -1.08 & $-8.6^{*}$ & -3.81 & $-6.61^{*}$ & -0.94 & -4.21 & 1.67 & 1.62 & -0.32 & -0.29 \\
\hline 10 & -0.02 & -0.2 & -3.83 & $-6.65^{*}$ & -0.33 & -1.29 & 2.50 & 1.07 & 1.31 & 1.01 \\
\hline
\end{tabular}

From the results shown in Table 4, it is evident that the Make in India initiative announcement has been beneficial to investors, as indicated by significant positive abnormal returns. The AARs on one day prior to the announcement are negative but insignificant, as soon as the announcement is made, positive and significant abnormal returns are evident up to day 3 . The Abnormal returns are maximum $(0.68 \%)$ and significant on the 2 nd day after the announcement, which depicts that Make in India has a significant and positive impact on stocks of manufacturing companies, and investors were benefited from the announcement. It is important to note that after day 3 of the post-announcement, the AARs showed a negative trend up to the 10th day. This negative trend may however be associated with the negative information released or an information that came in the limelight during the post-announcement of the Make in India initiative in various platforms. One such negative information is India's poor ranking (134th rank) in the World Bank's Ease of Doing Business Index. Furthermore, poor infrastructure, red tape, corruption and scams, and labor laws are among the issues that were discussed worldwide as being the major challenges before the practical and successful implementation of the Make in India initiative.

Following the standard deviation during the event window, a high degree of volatility within the sample is evident. From skewness and kurtosis, it is evident that positive returns were small 
and sustained for only a short period. Thus, it can be said that the Make in India initiation has significantly benefited the investors in wealth creation for a short period.

From CAARs, it cannot be said with much emphasis that the Make in India has any impact on the shareholder's wealth. On the event day and day one in post-announcement days, insignificant negative CAARs are evident, and on the 2nd, 3rd and 4th days, insignificant positive CAARs are evident. On this basis, a clear-cut conclusion cannot be derived. Therefore, small windows have been taken up for better understanding.

\begin{tabular}{|c|c|c|}
\hline \multicolumn{3}{|c|}{ Table No. 5: Small Windows for CAARs } \\
\hline Event Window & CAARs & T-Stats \\
\hline$(-10,+10)$ & -3.84 & $-6.65^{*}$ \\
\hline$(-1,+1)$ & 0.35 & 0.61 \\
\hline$(-2,+2)$ & 0.47 & 0.81 \\
\hline$(-3,+3)$ & 0.30 & 0.52 \\
\hline$(-4,+4)$ & -0.53 & -0.91 \\
\hline$(0,+1)$ & 0.44 & 0.77 \\
\hline$(0,+2)$ & 1.124 & 1.95 \\
\hline$(0,+3)$ & 1.44 & $2.49^{*}$ \\
\hline$(0,+4)$ & 1.20 & $2.07^{*}$ \\
\hline$(0,+5)$ & 0.29 & 0.49 \\
\hline$(0,+6)$ & -1.11 & -1.93 \\
\hline \multicolumn{3}{|c|}{ Source: Author's calculation } \\
\hline \multicolumn{2}{|c|}{ Significant at 5\% significant level } \\
\hline
\end{tabular}

The impact of announcement is tested around small windows of $(-1,+1),(-2,+2),(-3,+3)$, $(-4,+4),(0,+1),(0,+2),(0,+3),(0,+4),(0,+5)$ and a large window of $(-10,+10)$. Such small windows provide measure for accurately identifying the impact of the event announced and also information leakage if any. The windows of $(0,+3)$ and $(0,+4)$ show that buying securities on the day of the announcement and selling it on day 3 and 4 would have gained $1.44 \%$ and $1.20 \%$, respectively, to the investors. A negative return of $(0,+6)$ shows that the information is absorbed within 6 days of announcement. Investors gained the highest returns of $1.44 \%$ on $(0,+3)$; this window seems to be the best window from an investor's point of view.

Impact of Demonetization: The table no. 6 displays the AARs, CAARs and t-stats along with standard deviation, skewness and kurtosis.

The results signify that the demonetization announcement brought a depressing situation for the investors. It is apparent that Demonetization brought losses to the shareholders. AARs are negative and significant from the day of the announcement to the 6th day, which depicts the negative information is perceived by the investors; in other words, negative information is conveyed through Demonetization. The AARs is maximum (-2.314\%) on the 4th day, which indicates that the scenario for investors was not favorable, as, on a single day, investors lost their substantial portion of the investment. On the 7th day, a positive abnormal return of $1.551 \%$ is witnessed, but again, on the 8th day, a significant negative return is observed; however, a positive return is continued. From this, it can be clearly said that Demonetization does have a significant impact on the stocks of manufacturing companies.

Following the standard deviation, a high degree of volatility within the sample around the event window is evident. Further, the short-term negative abnormal returns and their size is confirmed from skewness and kurtosis, respectively. It indicates that the Demonetization has significantly affected the market for a short period.

All CAARs in the post-demonetization announcement period is negative and significant, implying investors swallowed a bitter taste in the form of loss due to Demonetization. The investors faced a significant loss of $8.118 \%$ on the entire 6 days in the post-announcement period. 


\begin{tabular}{|c|c|c|c|c|c|c|c|c|c|c|}
\hline Event & $\operatorname{AARS}(\%)$ & T-Stats & CAARs $(\%)$ & T-Stats & Median & Min & Max & StdDev & Skewness & Kurtosis \\
\hline Days & & & & & $\mathrm{AR}(\%)$ & $\mathrm{AR}(\%)$ & $\mathrm{AR}(\%)$ & $\operatorname{AR}(\%)$ & & \\
\hline-10 & 0.52 & $4.72 *$ & 0.52 & 1.09 & 0.33 & -2.20 & 4.63 & 1.53 & 1.08 & 2.21 \\
\hline-9 & -0.12 & -1.15 & 0.39 & 0.82 & -0.30 & -4.67 & 2.77 & 1.68 & -0.66 & 1.58 \\
\hline-8 & -0.90 & $-8.11 *$ & -0.50 & -1.05 & -0.52 & -9.47 & 2.33 & 2.46 & -2.24 & 7.53 \\
\hline-7 & 0.69 & $6.20^{*}$ & 0.18 & 0.38 & 0.38 & -2.27 & 6.67 & 2.30 & 1.49 & 2.12 \\
\hline-6 & 0.25 & $2.32 *$ & 0.44 & 0.92 & 0.20 & -1.02 & 1.99 & 0.76 & 0.28 & 0.06 \\
\hline-5 & -0.02 & -0.20 & 0.42 & 0.87 & -0.08 & -2.75 & 5.24 & 1.77 & 1.21 & 3.06 \\
\hline-4 & -0.71 & $-6.43^{*}$ & -0.29 & -0.61 & -0.97 & -4.01 & 4.63 & 1.65 & 1.47 & 5.66 \\
\hline-3 & -0.46 & $-4.16^{*}$ & -0.76 & -1.58 & -0.50 & -2.27 & 1.97 & 1.18 & 0.22 & -0.41 \\
\hline-2 & -1.42 & $-12.77^{*}$ & -2.18 & $-4.54 *$ & -1.17 & -7.17 & 4.29 & 2.57 & -0.30 & 1.12 \\
\hline-1 & 0.35 & $3.19^{*}$ & -1.83 & $-3.80^{*}$ & -0.06 & -3.34 & 6.23 & 2.16 & 1.32 & 2.38 \\
\hline 0 & -0.71 & $-6.55^{*}$ & -2.56 & $-5.31^{*}$ & -0.46 & -3.60 & 3.43 & 1.68 & 0.38 & 0.38 \\
\hline 1 & -0.33 & $-3.01^{*}$ & -2.90 & $-6.01^{*}$ & -0.97 & -3.99 & 4.97 & 2.95 & 0.10 & -1.05 \\
\hline 2 & -0.53 & $-4.76^{*}$ & -3.43 & $-7.11^{*}$ & -0.71 & -4.35 & 6.34 & 2.73 & 0.32 & 0.77 \\
\hline 3 & -1.45 & $-13.06^{*}$ & -4.89 & $-10.14^{*}$ & -1.87 & -4.19 & 5.15 & 2.13 & 1.29 & 3.76 \\
\hline 4 & -2.31 & $-20.73^{*}$ & -7.20 & $-14.93^{*}$ & -2.48 & -6.13 & 1.49 & 2.51 & 0.07 & -1.34 \\
\hline 5 & -0.42 & $-3.76^{*}$ & -7.62 & $-15.81^{*}$ & -0.66 & -3.62 & 4.34 & 2.30 & 0.72 & -0.41 \\
\hline 6 & -0.56 & $-5.05^{*}$ & -8.18 & $-16.98^{*}$ & -0.52 & -3.81 & 2.90 & 1.51 & -0.01 & 0.85 \\
\hline 7 & 1.55 & $13.89^{*}$ & -6.63 & $-13.76^{*}$ & 1.54 & -1.17 & 4.24 & 1.47 & 0.14 & -0.22 \\
\hline 8 & -0.65 & $-5.88^{*}$ & -7.29 & $-15.12^{*}$ & -0.43 & -5.86 & 2.80 & 1.82 & -0.90 & 2.60 \\
\hline 9 & 0.90 & $8.09^{*}$ & -6.38 & $-13.25^{*}$ & 0.70 & -0.56 & 2.89 & 1.04 & 0.39 & -0.89 \\
\hline 10 & 0.92 & $8.30^{*}$ & -5.46 & $-11.32 *$ & 0.60 & -2.26 & 5.25 & 1.84 & 0.89 & 1.31 \\
\hline \multicolumn{11}{|c|}{ Source: Author's calculation } \\
\hline \multicolumn{11}{|c|}{ Significant at $5 \%$ level $( \pm 1.96)$} \\
\hline
\end{tabular}

For better understanding and to depict the impact, short term windows are presented in table no. 7 below:

\begin{tabular}{|c|c|c|}
\hline \multicolumn{3}{|c|}{ Table No. 7: Short term windows } \\
\hline Event Window & CAARs & T-Stats \\
\hline$(-10,+10)$ & -5.46 & $-11.32^{*}$ \\
\hline$(-4,+4)$ & -8.04 & $-16.68^{*}$ \\
\hline$(-3,+3)$ & -4.59 & $-9.52^{*}$ \\
\hline$(-2,+2)$ & -2.67 & $-5.53^{*}$ \\
\hline$(-1,+1)$ & -0.71 & -1.44 \\
\hline$(0,+1)$ & -1.06 & $-2.24^{*}$ \\
\hline$(0,+2)$ & -1.60 & $-3.31^{*}$ \\
\hline$(0,+3)$ & -3.05 & $-6.34^{*}$ \\
\hline$(0,+5)$ & -5.79 & $-12.01^{*}$ \\
\hline \multicolumn{3}{|c|}{ Source: Author's calculation } \\
\hline Significant at 5 & ificant le & $1( \pm 1.96)$ \\
\hline
\end{tabular}

The impact of announcement is tested around small windows of $(-1,+1),(-2,+2),(-3,+3)$, $(-4,+4),(0,+1),(0,+2),(0,+3),(0,+4),(0,+5)$ and large window of $(-10,+10)$. In the entire window, CAARs are negative and significant. From this it is clear that demonetization impacted the market adversely and investors saw a sharp decline in their investment due to demonetization.

Impact of GST implementation: In table no 8, the impact of the GST implementation is presented. 


\begin{tabular}{|c|c|c|c|c|c|c|c|c|c|c|}
\hline Event & $\operatorname{AARS}(\%)$ & T-Stats & CAARs $(\%)$ & T-Stats & Median & Min & Max & StdDev & Skewness & Kurtosis \\
\hline Days & & & & & $\operatorname{AR}(\%)$ & $\mathrm{AR}(\%)$ & $\operatorname{AR}(\%)$ & $\operatorname{AR}(\%)$ & & \\
\hline-10 & -0.52 & $-4.33^{*}$ & -0.52 & -1.83 & -0.11 & -4.26 & 1.73 & 1.31 & -1.11 & 2.53 \\
\hline-9 & -0.41 & -3.398 & -0.92 & $-3.27^{*}$ & -0.32 & -1.84 & 1.17 & 0.75 & -0.01 & -0.29 \\
\hline-8 & -0.05 & -0.38 & -0.97 & $-3.43^{*}$ & -0.32 & -2.14 & 2.02 & 1.10 & 0.17 & -0.45 \\
\hline-7 & -0.01 & -0.05 & -0.97 & $-3.45^{*}$ & -0.19 & -1.40 & 2.37 & 0.94 & 0.69 & 0.61 \\
\hline-6 & -0.18 & -1.55 & -1.16 & $-4.10^{*}$ & -0.13 & -2.31 & 1.79 & 1.07 & -0.17 & -0.20 \\
\hline-5 & -0.16 & -1.31 & -1.32 & $-4.66^{*}$ & -0.06 & -2.18 & 1.63 & 1.00 & -0.51 & -0.27 \\
\hline-4 & -0.01 & -0.05 & -1.32 & $-4.68^{*}$ & -0.03 & -1.49 & 1.77 & 0.93 & 0.16 & -0.72 \\
\hline-3 & 0.43 & $3.60^{*}$ & -0.89 & $-3.16^{*}$ & 0.40 & -0.93 & 2.45 & 0.83 & 1.14 & 1.91 \\
\hline-2 & 0.25 & $2.11^{*}$ & -0.64 & $-2.27^{*}$ & 0.15 & -1.26 & 1.86 & 0.79 & 0.41 & 0.23 \\
\hline-1 & 0.38 & $3.16^{*}$ & -0.26 & -0.93 & 0.07 & -1.86 & 2.14 & 1.14 & -0.03 & -1.12 \\
\hline 0 & 0.14 & 1.15 & -0.13 & -0.44 & -0.27 & -1.22 & 3.14 & 1.17 & 1.43 & 1.54 \\
\hline 1 & -0.32 & $-2.65^{*}$ & -0.44 & -1.57 & -0.39 & -2.08 & 1.69 & 1.19 & -0.02 & -0.98 \\
\hline 2 & 0.71 & $5.94^{*}$ & 0.27 & 0.95 & 0.04 & -0.66 & 3.93 & 1.16 & 1.40 & 1.78 \\
\hline 3 & -0.11 & -0.89 & 0.16 & 0.57 & -0.11 & -1.78 & 1.49 & 0.94 & -0.33 & -0.39 \\
\hline 4 & 0.63 & $5.31 *$ & 0.80 & $2.82 *$ & 0.40 & -1.30 & 4.08 & 1.57 & 0.76 & -0.26 \\
\hline 5 & 0.05 & 0.42 & 0.85 & $3.00^{*}$ & -0.33 & -1.85 & 7.09 & 2.00 & 2.54 & 8.07 \\
\hline 6 & -0.08 & -0.64 & 0.77 & $2.73^{*}$ & -0.06 & -2.09 & 2.55 & 1.24 & 0.46 & 0.21 \\
\hline 7 & -0.08 & -0.64 & 0.69 & $2.46^{*}$ & 0.02 & -1.22 & 2.07 & 0.79 & 0.87 & 1.95 \\
\hline 8 & -0.44 & $-3.68^{*}$ & 0.25 & 0.90 & -0.23 & -3.06 & 0.78 & 1.04 & -1.44 & 1.86 \\
\hline 9 & 0.89 & $7.49^{*}$ & 1.15 & $4.07 *$ & 0.59 & -1.02 & 5.94 & 1.56 & 1.92 & 4.94 \\
\hline 10 & -0.06 & -0.52 & 1.09 & $3.85^{*}$ & 0.02 & -2.78 & 1.56 & 1.07 & -0.97 & 1.44 \\
\hline \multicolumn{11}{|c|}{ Source: Author's calculation } \\
\hline \multicolumn{11}{|c|}{ Significant at $5 \%$ significant level $( \pm 1.96)$} \\
\hline
\end{tabular}

The result signifies that the GST implementation announcement has brought confusion and fear in the mindset of the investors. The AARs and CAARs on the event day are positive and negative, respectively but not significant. However, the AAR is negative and significant on 1st day, and positive and significant on day 2 on post-announcement days. The CAARs are not significant from event day to 3rd day in post-announcement days. These fluctuations in the return series reflects confusion regarding the impact of the GST implementation announcement. Therefore, for better understanding and insight of the impact, short-term windows are presented in table no. 9 .

\begin{tabular}{|c|c|c|}
\hline \multicolumn{3}{|c|}{ Table No. 9: Short term window } \\
\hline \multicolumn{3}{|c|}{ for GST implementation } \\
\hline window & CAARs & T-test \\
\hline$(-4,+4)$ & 2.11 & $7.48^{*}$ \\
\hline$(-3,+3)$ & 1.48 & $5.25^{*}$ \\
\hline$(-2,+2)$ & 1.16 & $4.10^{*}$ \\
\hline$(-1,+1)$ & 0.20 & 0.70 \\
\hline$(0,-1)$ & 0.51 & 1.82 \\
\hline$(0,-2)$ & 0.77 & $2.71^{*}$ \\
\hline$(0,+1)$ & -0.18 & -0.64 \\
\hline$(0,+2)$ & 0.53 & 1.87 \\
\hline$(0,+3)$ & 0.42 & 1.50 \\
\hline \multicolumn{3}{|c|}{ Source: Author's calculation } \\
\hline Significant at $5 \%$ significant level $( \pm 1.96)$ \\
\hline
\end{tabular}

The impact of announcement is tested around small windows of $(-1,+1),(-2,+2),(-3,+3)$, $(-4,+4),(0,-1),(0,-2),(0,+1),(0,+2)$, and $(0,+3)$. From the small windows, it is observed 
that the CAARs of $(-1,+1),(0,+2)$ and $(0,+3)$ are positive but not significant, but the CAARs of $(0,+1)$ is negative and insignificant. However, the CAARs of $(-2,+2)$ and $(-3,+3)$ and $(-4$, $+4)$ are positive and significant. Based on the AARs, CAARs on the event day and small windows of $(-1,+1),(0,+1),(0,+2)$ and $(0,+3)$ during the event days, it can be concluded that the GST implementation announcement has no impact on the stocks of manufacturing companies of India.

\section{Conclusion}

The present study is based on a lack of literature and contradictory views regarding macroeconomic events and their impact on the stock market. In this paper Make in India, Demonetization and GST implementation announcements are taken as events based on their importance, impact and contradictory views among finance subject experts and literature. The event study methodology with 21 days event window accompanied by a parametric t-test for significance testing is employed in the study. The study has been divided into three-fold. In first fold, the impact of Make in India and on second, the impact of Demonetization and on the third fold, the impact of the GST implementation announcement is studied.

The evidence from the Make in India initiative suggested that the positive information is conveyed and perceived by the market, implying the positive impact of the event on the market. The findings showed that the abnormal returns are maximum $(0.68 \%)$ and significant on the 2nd day after the announcement, which clearly indicated that the Make in India program has a significant impact on the stocks of manufacturing companies and investors are benefited from the announcement. However, the results for Demonetization are exactly the opposite of the Make in India initiative. The results from the event analysis suggest that the announcement of the Demonetization is perceived as negative information by the market as the AARs are significantly negative up to the 6th day in post-announcement and it is maximum (-2.314\%) on the 4th day, which indicates the unfavorable scenario for investors, as on single day investors lost significant portion of their investment. In the case of the GST, the market did not respond to the announcement. The AARs and CAARs on the event day are positive and negative, respectively but not significant. The small windows of $(-1,+1),(0,+1),(0,+2)$ and $(0,+3)$ during the event days are also not significant. Based on the AARs, CAARs on the event day and small windows during the event days, it is concluded that the GST implementation announcement has no impact on the stocks of manufacturing companies of India.

A high degree of volatility is witnessed on the announcement of the Make in India initiative with 2.19 degree of standard deviation as compared to that of Demonetization (1.68), and GST implementation (1.17). Further, from the results of skewness and kurtosis it is evident that the abnormal returns were small and sustained for only for a short period.

The observations of the present study based on three different events form the base for the investor in making an investment decision, in the event of announcements of similar events in future to come. It will not only be helpful in framing the investment strategies in manufacturing sectors but also to the sectors that are allied to manufacturing sector like cement, construction, Pharma, and others. From the conclusion of the study, it can be stated that during the announcement of the event that is motivated with boosting and enhancing the economy, the capital market tends to rise as compared to the events that bring specific changes in the economy like that of GST. In other words, announcements of events that have an immediate financial implication on the firms as well as on the general public makes the capital market go down. However, it is to be noted here that investors should also examine other factors too within their capacity before making any investment decision.

In this study, only the Indian Manufacturing sector companies have been studied to see the impact of three governmental announcements on their share prices. However, a further study with other sectors can be conducted to see and compare the impact of the said events on their respective share prices. Again, event study, along with other statistical tool such as GARCH Model, and Regression can be employed for better and robust results. 


\section{Declaration of Conflicting Interests}

The authors declared no potential conflicts of interest with respect to the research, authorship and/or publication of this article.

\section{Funding}

The authors received no financial support for the research, authorship and/or publication of this article.

\section{REFERENCES}

[1] R, S. (2019). Impact of Demonetisation on Indian Stock Market. Research Review International Journal of Multidisciplinary, 4(2), 633-638.

[2] Anwar, S., Singh, S., \& Jain, P. K. (2017). Impact of Cash Dividend Announcements: Evidence from the Indian Manufacturing Companies. Journal of Emerging Market Finance, 16(1), 1-32.

[3] Anoop, P., Parab, N., \& Reddy, Y. V. (2018). Analyzing the Impact of Demonetization on the Indian Stock Market: Sectoral Evidence using GARCH Model. Australasian Accounting, Business and Finance Journal, 12(2), 104-116.

[4] Barwer, R., \& Sharma, M. L. (2019). Make in India: A Dream to Reality and Indian Textile Sector. International journal of basic and applied research, 9(2), 94-102.

[5] Bhat, T. P. (2014). INDIA: Structural Changes in the Manufacturing Sector and Growth Prospect. Institute for Studies in Industrial Development, 1-21. Retrieved from http://isid.org.in/pdf/WP173.pdf.

[6] Brown, S. J. (1980). Measuring Security Price Performance. Journal of Financial Economics, 8(3), 205-258.

[7] Cantore, N., Clara, M., Lavopa, A., \& Soare, C. (2017). Manufacturing as an engine of growth: Which is the best fuel? Structural Change and Economic Dynamics, 42, 56-66.

[8] Chauhan, S., \& Kaushik, N. (2017). Impact of Demonetization on Stock Market: Event Study Methodology. Indian Journal of Accounting, XLIX(1), 127-132.

[9] Dahal, M., \& Das, J. (2020). Impact of Demonetization on Banking Sector Stock. Indian Economy 2020: Current Issues and Future Prospects (pp. 226-245).

[10] Dick, C. D., \& Wang, Q. (2010). The economic impact of the Olympic Games: Evidence from stock markets. Applied Economics Letters, 17(9), 861-864.

[11] Fama, E. F., Fisher, L., Jensen, M. C., \& Roll, R. (1969). The Adjustment of Stock Prices to New Information. International Economic Review, 10(1), 1-21.

[12] Fernandez, R., \& Palazuelos, E. (2018). Measuring the role of Manufacturing in the productivity growth of the European economies (1993-2007). Structural Change and Economic Dynamics, 1-39.

[13] Gauba, R., Nandita, \& Dhingra, R. (2016). Make in India-An Initiative to Change the Economic Landscape of the Country. Amity Journal of Economics, 1(2), 88-104.

[14] Gaur, A. D., \& Padiya, J. (2017). Exploring 'Make in India' Campaign \& Emerging FDI trends in IT\& BPM Sector in India. Journal of Business Sciences, 1(2), 42-57.

[15] Girish, G. P. (2019). Impact of Implementation of Goods and Services Tax on Nifty 50 Index of National Stock Exchange of India. Theoretical Economics Letters, 9, 172-179.

[16] Gulhane, S., \& Turukmane, R. (2017). Effect of make in India on textile sector. Journal of Textile Engineering \& Fashion Technology, 3(1), 551-555.

[17] Haraguchi, N., Cheng, C. F., \& Smeets, E. (2017). The Importance of Manufacturing in Economic Development: Has this Changed? World Development, XX, 1-23.

[18] India Brand Equity Foundation. (2015). Role of Manufacturing in Employment Generation in India. Retrieved from https://www.ibef.org/download/Role-of-Manufacturing-in-Employment-Generation-inIndia.pdf

[19] Jain, R., \& Gupta, M. (2018). Impact of Demonetization on Indian Stock Market. Vivekananda Journal of Research , 7(1), 110-118.

[20] Joy, O. M., Litzenberger, R. H., \& McEnally, R. W. (1977). The Adjustment of Stock Prices to Announcements of Unanticipated Changes in Quarterly Earnings. Journal of Accounting Research, 15(2), 207-225.

[21] Khanna, K., \& Gogia, N. (2014). A Pragmatic Study of Budget Announcements \& Stock Market Performance: India, US \& UK Panorama. International Journal of Business and Management Research, IV (II), 35-38.

[22] Kumar, S., \& Dubey, R. K. (2016). FDI Flow and Industrial Production-An impact analysis of Make in India Campaign. International Journal of Research in Economics and Social Sciences, 6(1), 75-84.

[23] Kumar, V., \& Bhatia, B. S. (2018). The effect of demonetisation in Indian stock market with special reference to sectoral indices: An event study. 1-18.

[24] Lahiri, A. (2020). The Great Indian Demonetization. Journal of Economic Perspectives, 34(1), 55-74.

[25] Lakshmi, \& Alex, R. (2018). Effect of GST Rate Announcement on Sectorial Indices of National Stock Exchange. Indian Journal of Commerce \& Management Studies, IX(1), 29-36. 
[26] Mackinlay, A. C. (1997). Event-Studies in Economics and Finance. Journal of Economic Literature, XXXV, 13-39.

[27] Maitra, D., \& Dey, K. (2012). Dividend Announcement and Market Response in Indian Stock Market: An Event-Study Analysis. Global Business Review, 13(2), 269-283.

[28] Mehta, R. (2020). A Study on the Impact of Demonetization and GST on the Realty Index of India. International Journal of Research in Engineering, Science and Management, 3(3), 1-6.

[29] Mehta, Y., \& A, J. R. (2017). Manufacturing Sectors in India: Outlook and Challenges. Procedia Engineering, 90-104. Retrieved from https://www.sciencedirect.com/ science/article/pii/S187770581730173X?via\%3Dihub.

[30] Mirman, M., \& Sharma, R. (2010). Stock market reaction to Olympic Games announcement. Applied Economics Letters, 17(5), 463-466.

[31] Mishra, P., \& Taruna. (2016). Role of Make in India as driver of growth in manufacturing sector. International Journal of Applied Research, 2(1), 591-594.

[32] Mohanty, M. (2008). The Financial Information Content of Celebrity Endorser: An Event Study Analysis. Paradigm, 12(1), 89-97.

[33] Pal, S., \& Garg, A. K. (2019). Macroeconomic surprises and stock market responses-A study on Indian stock market. Cogent Economics \& Finance, 1-31.

[34] Panwar, V., \& Nidugala, G. K. (2017). Indian Stock Market Reaction to Interest Rate and Inflation Announcements. 19th International Scientific Conference on Economic and Social Development, (pp. 424-434). Melbourne, Australia.

[35] Peterson, P. P. (1989). Event Studies: A Review of Issues and Methodology. Quarterly Journal of Business and Economics, 28(3), 36-66.

[36] Pettit, R. R. (1972). Dividend Announcements, Security Performance, and Capital Market Efficiency. The Journal of Finance, XXVII(5), 993-1007.

[37] Sagar, A. (2016). Make in India Program - An Analytical Review. International Journal of Management and Applied Science, 2(6), 134-136.

[38] Sahoo, B. B. (2018). Make in India: Impact on Indian Economy. International Journal of Research Culture Society, 2(3), 483-489.

[39] Saran C, S. (2018). Effect of Declaration of GST Rates and Changes in the GST Rates on the Sectorial Indices of National Stock Market. Indian Journal of Commerce \& Management Studies, IX(2), 51-58.

[40] Saravanakumar, S. (2011). Impact of Dividend Announcement on Indian Bourses. Global Business Review, 12(3), 401-413.

[41] Sharpe, W. F. (1963). A simplified model for portfolio analysis. Management Science, 9(2), 277-293.

[42] Sharma, P., \& Sain, M. (2017). A Review of Goods and Services Tax (GST): Impact on Indian Stock exchanges and various stock Sectors. International Journal of Scientific Research and Management, 5(11), 7418-7422.

[43] Sharpe, W. F. (1964). Capital Asset Process: A Theory of Market Equilibrium under Conditions of Risk. The Journal of Finance, XIX(3), 425-442.

[44] Sheoran, S. K. (2017). Make in India campaign and India's IT-BPM sector. International Journal of Applied Research, 3(1), 471-475.

[45] Shettar, R. M. (2017). Impact of Make in India Campaign: A Global Perspective. Journal of Research in Business and Management, 5(2), 1-6.

[46] Shukla, K., Purohit, M., \& Gaur, S. P. (2017). Studying 'Make in India' from the Lens of Labour Reforms. Management and Labour Studies, 42(1), 1-19.

[47] Solanki, A. H., \& Tank, H. (2018). Impact of Demonetization on Selected BSE Indices. Indian Journal of Accounting, 50(1), 115-121.

[48] Srivastava, R. (2019). Impact of "Make in India" in Indian Economy. International Journal of Trend in Scientific Research and Development, 3(3), 429-432.

[49] Szirmai, A., \& Verspagen, B. (2015). Manufacturing and economic growth in developing countries, 19502005. Structural Change and Economic Dynamics, 34, 46-59.

[50] Taqi, M., Ansari, M. S., \& Ajmal, M. (2018). Demonetization and its Impact on Indian Capital Market. Pacific Business Review International, 11(3), 51-58.

[51] The Economic Times. (2020). GST will completely transform India's tax structure: Shaktikanta Das. Retrieved 2020, from https://economictimes.indiatimes.com/tdmc/your-money/gst-will-completelytransform-indias-tax-structure-shaktikanta-das/printarticle/53541343.cms

[52] Thippeswamy, E. (2018). Impact of Demonetization on Tax Revenue in India: An Analysis. International Journal of Multidisciplinary, 3(4), 57-62.

[53] Thomas, S., \& Shah, A. (2002). Stock Market Response to Union Budget. Economic and Political Weekly, $37(5), 455-458$.

[54] Togadiya, J. B., \& Oza, V. (2020). Does GST a game-changer for Indian FMCG companies' share return? (Event Study Analysis). Journal of Engineering Sciences, 11(3), 637-653. 